\title{
Hepatoprotective potentials of the methanolic leaf extract of Jatropha curcas (LINN) on cadmium induced toxicity in rabbit
}

\author{
Adejumobi A.E.*, Areola J.O and Babalola 0.O. \\ Department of Biochemistry, Obafemi Awolowo University, Ile Ife, Nigeria \\ *Corresponding Author E- mail: doctorbablo@yahoo.com
}

\begin{abstract}
This study was carried out to investigate the possible hepatoprotective potentials of methanolic leaf extract of Jatropha curcas Linn on cadmium induced hepatotoxicity and oxidative stress in rabbits. Sixteen matured rabbits were used for the study; they were divided into four groups and treated as follows: Group I (control) was treated with normal saline $(0.85 \% \mathrm{w} / \mathrm{v} \mathrm{NaCl})$ at $2 \mathrm{ml} / \mathrm{kg}$ body weight per day. Group II were treated with only cadmium chloride at $1.25 \mathrm{mg} / \mathrm{kg}$ body weight per day. Groups III and IV were pre-treated with $300 \mathrm{mg} / \mathrm{kg}$ body weight per day of Jatropha curcas extract and vitamin E respectively, one hour later, cadmium chloride was administered to them at $1.25 \mathrm{mg} / \mathrm{kg}$ body weight. All the animals were treated orally for 10 days. The animals were sacrificed on day 11 , blood, liver and kidneys were removed and preserved for biochemical analyses. The liver samples were digested with mixture of concentrated trioxonitrate (V) acid $\left(\mathrm{HNO}_{3}\right)$ and hydrochloric acid $(\mathrm{HCl})(1: 4 \mathrm{v} / \mathrm{v})$. Cadmium concentrations in the liver were determined by atomic absorption spectroscopy (AAS). The concentrations of total plasma protein, albumin, uric acid and the activities of hepatic marker enzymes; alanine aminotransferase (ALT), aspartate aminotransferase (AST), and gamma glutamyltransferase (GGT) were determined in the plasma and liver homogenates by standard procedures. The result of phytochemical screening revealed that flavonoids, tannins, terpenoids steroids, phlobatanins and saponins were present in the extract. The analysis by atomic absorption spectroscopy of the liver revealed that there were traces of cadmium $(0.01 \mu \mathrm{g} / \mathrm{g})$ in the liver of animals pre-treated with vitamin $E$ and Jatropha curcas extract while the concentration of cadmium in the liver of only cadmium group was $0.14 \mu \mathrm{g} / \mathrm{g}$. Additionally, the activities of hepatic marker enzymes (AST, ALT, GGT) were elevated in cadmium only treated group but pretreatment with methanolic extract of Jatropha curcas reduced significantly $(p<0.05)$ the activities of these enzymes. The total protein and uric acid concentrations were also significantly reduced in cadmium treated group when compared with the extract pre-treated group. Comparison of the activities of hepatic marker enzymes (ALT, AST and GGT) in vitamin E and Jatropha curcas extract pre-treated groups revealed that ALT, AST and GGT activities were not significantly different in these groups. Also, albumin and uric acid concentrations were not significantly different between the groups. The results of biochemical studies of blood samples and liver homogenates revealed significant increase in the levels of maker enzymes reflecting liver injury caused by cadmium while pre-treatment with Jatropha curcas extract reduced the activities of the enzymes. Oral administration of methanolic extract of Jatropha curcas at 300 $\mathrm{mg} / \mathrm{kg}$ body weight in this study was able to reduce the hepatotoxic effects of cadmium toxicity at 1.25 $\mathrm{mg} / \mathrm{kg}$ body weight. This suggests that methanolic leaf extract of Jatropha curcas might possess hepatoprotective effect. The results of this investigation has further confirmed the inherent therapeutic properties of Jatropha curcas and also justified its uses in traditional medicine to cure various ailments in Asia, Africa and Latin America.
\end{abstract}

Keywords: Jatropha curcas, Cadmium, Rabbit, Heavy Metals, Hepatotoxicity.

\section{INTRODUCTION}

Heavy metals occur as natural constituents in the earth crust and are persistent environmental contaminants since they are not degraded or destroyed. To a large extent, they enter the body system through food, air, and water and bio-accumulate over a period of time. Cadmium is a classic- elemental toxicant that shows 
various adverse effects and can be fatal depending on the dose. The frequency of exposure to cadmium is gradually on the rise as a result of increase in the production and usage of materials like tobacco, cement, phosphate fertilizer and other materials containing cadmium. Cadmium is a non-essential toxic heavy metal, which is known to affect cellular processes through membrane damage, disruption of electron transport, enzyme inhibition and DNA alteration (Godt et al., 2006, Babalola and Areola, 2010).

Upon acute exposure to cadmium, hepatotoxicity is indicated by changes such as swelling of hepatocytes, fatty changes, and focal necrosis or necrosis in a wide area. Cadmium accelerates lipid peroxidation by stimulating the peroxidation chain reaction in the target organs, resulting in the generation of reactive oxygen species (Oteiza et al., 1999).

Liver is one of the largest organs in human body and the chief site for biotransformation of toxic materials. So it plays an important role in the maintenance and regulation of the body homeostasis (Ward and Daly, 1999). However if the liver is continuously exposed to environmental toxins which include the heavy metals, various ailments like liver cirrhosis and fatty liver disease could result ( Subramonium and Pushpangadan, 1999).

There are not many drugs for the treatment of liver damage, therefore, many folk remedies from plants origin are tested for their potential antioxidant and hepatoprotective effects in experimental animal model. The demand for natural antioxidants has increased as they are viewed as promising free radical scavengers. With the current resurgence of scientific research in herbal medicine, it is becoming clearer that the medicinal herbs are becoming better alternatives to synthetic ones; though many synthetic drugs in use today were derived from medicinal herbs. According to one estimate, only $20 \%$ of the plant flora has been studied and $60 \%$ of synthetic medicines owe their origin to plants (Cowan, 1999).

Jatropha curcas Linn is a multipurpose and drought resistant perennial plant which belongs to the family Euphorbiaceae. It is known commonly as Physic nut or Purging nut, the oil produced from the nut of this plant is used as a biodiesel. The methanolic leaf extract was reported to have antiviral activity (Gupta et al; 1996). The ethanolic extract of the defatted leaves and twigs had been shown to have anti-leukemic activity (Hufford and Oguntimehin, 1978). The butanolic extract of dried leaves of Jatropha curcas and decoction of dried root bark was shown to possess antispasmodic activity (Kambu et al., 1990).

The current study on Jatropha curcas was designed to investigate the possible hepatoprotective activity of its leaf extracts on cadmium induced toxicity in rabbits.

\section{MATERIALS AND METHODS}

\section{Plant Material}

Fresh leaves of Jatropha curcas were collected in the month of November, 2009 from Ikire town in Osun State, Nigeria. They were identified and authenticated by Mr. Ibhanesebor G.A. of the Department of Botany, O.A.U Ife-Ife.

\section{Reagents and Chemicals}

All the reagents used in the study were of analytical grade. They were obtained from British Drug House Limited (BDH) London, Sigma Fine Chemicals Limited, Upsalla, Sweden, Fluka Chemical Company PIc. Germany. Reagent kits to assay for the enzymes were obtained from Randox Laboratories Ltd, United Kingdom. All solutions, buffers and reagents were prepared with glass-distilled water.

\section{Extract Preparation}

The extract was prepared according to the procedure described by Uche and Aprioku,( 2008). The leaves were air dried for sixteen days in the laboratory after which they were ground into fine powder. The powdered leaves $(500 \mathrm{~g})$ were subjected to Soxhlet extraction using methanol as solvent for 12 hours; the filtrate was evaporated to dryness using Edward vacuum evaporator. The yield was calculated to be $80.15 \mathrm{~g}$ representing $16.03 \%$.It was kept in air tight container for future analyses.

\section{Phytochemical Screening}

The extract was screened for terpenoid, steroid, tannin, saponin, flavonoid, cardiac glycoside and phlobatannin according to standard procedures (Harborne 1998, Edeoga et al., 2005)

\section{Experimental Design}

Sixteen female rabbits were used for this study. The animals were allowed to acclimatize under laboratory condition for two months. At the end of the acclimatization, the animals were grouped randomly into four (4 animals per group). Each group was treated orally once per day for 10 days as follows: Group I (Control): Animals in this group received $2 \mathrm{ml} / \mathrm{kg}$ body weight of 
normal saline. Group II (Cadmium only treated): Animals in this group received $1.25 \mathrm{mg} / \mathrm{kg}$ body weight of cadmium chloride only. Group III( Extract pre-treated): Animals in this group were pre-treated with $300 \mathrm{mg} / \mathrm{kg}$ of Jatropha curcas leaf extract and one hour later, cadmium chloride was administered ( $1.25 \mathrm{mg} / \mathrm{kg}$ body weight). Group IV (Vitamin E pre-treated): Animals in this group were given vitamin $E(300 \mathrm{mg} / \mathrm{kg}$ body weight) before the administration of cadmium chloride $(1.25 \mathrm{mg} / \mathrm{kg}$ body weight) after 1 hour. Prior to the administration of the extract, it was reconstituted in olive oil at a concentration equivalent to $300 \mathrm{mg} / \mathrm{kg}$ body weight. The animals were sacrificed at the end of the treatment period, blood was collected through cardiac puncture into clean bottles containing anticoagulant, the liver and the kidneys were excised for various biochemical analyses.

\section{Digestion of Liver Samples for AAS Analysis}

The acid digestion of the liver was carried out as described by Babalola and Areola (2010). The liver (1 g) of each animal was homogenized in $5 \mathrm{ml}$ of mixture of concentrated $\mathrm{HNO}_{3}$ and $\mathrm{HCl}(1: 4 \mathrm{v} / \mathrm{v})$. The homogenates were transferred into test tubes, covered with cotton wool and left on bench overnight to solubilize the tissue. The mixture was heated at $100^{\circ} \mathrm{C}$ in water bath for 20 minutes and allowed to cool, followed by the addition of $1.0 \mathrm{ml}$ of hydrogen peroxide. The sample was then diluted to a final volume of $25 \mathrm{ml}$ with distilled water and stored in a $30 \mathrm{ml}$ polyethylene bottle for analyses by Atomic Absorption Spectrophotometer.

\section{Preparation of Liver Homogenates and Blood Plasma}

Liver samples $(2 \mathrm{~g})$ were homogenized in $10 \mathrm{ml}$ of cold phosphate buffer $(\mathrm{pH} 7.4,0.1 \mathrm{M})$ and centrifuged at 4000 rpm for 30 minutes. The supernatants were collected into clean sterile bottles and kept in freezer for further analyses. The blood collected from each animal in heparinized bottle was centrifuged at $3000 \mathrm{rpm}$ for 30 minutes. The supernatants were collected into clean sterile bottles and kept in the freezer for further analyses.

\section{Biochemical Estimation}

\section{Metabolites}

The total protein concentration was determined using Biuret reaction method as described by Cannon et al., (1974). Albumin concentration was determined using a method as described by Pinnel and Northan (1978). Uric acid in the liver and plasma was estimated as described by Fossati et al., (1980).

\section{Assay of Enzyme Activities}

The activities of aminotransferases (AST and ALT) were assayed as described by Reitman and Frankel (1957) using randox diagnostic kits. The activity of gamma glutamyltransferase (GGT) was assayed according to the method of Teitz (1957)) using randox diagnostic kits.

\section{Statistical Analyses}

Values of biochemical parameters were expressed as Mean \pm SEM. The statistical analysis was carried out using analysis of variance (ANOVA) and Student $t$ test. Comparisons were made between different Groups, values $<0.05$ were considered as significant

\section{RESULTS}

The phytochemical tests revealed the presence of flavonoids, steroids, terpenoids, tannins, phlobatannins, and saponins while cardiac glycoside was absent as shown in Table 1

The analysis by atomic absorption spectroscopy of the liver revealed that there were traces of cadmium $(0.01$ $\mu \mathrm{g} / \mathrm{g}$ ) in the liver of animals pre-treated with vitamin $\mathrm{E}$ and Jatropha curcas extract while the concentration of cadmium in the liver of only cadmium group was 0.14 $\mu \mathrm{g} / \mathrm{g}$. The results of biochemical analyses of the plasma from different treatment groups are shown in tables 2 and 3. Effects of Cadmium and Jatropha curcas on total protein, albumin and globulin are displayed in Table 2 while Table 3 showed the effects on the hepatic marker enzymes; ALT (Alanine aminotransferase), AST (Aspartate alanine aminotransferase), GGT (Gamma glutammyltransferase). Concentration of metabolites and the activities of the enzymes were affected differently by cadmium in treated groups when compared with the control groups. It was evident from Table 3, where the biochemical parameters were compared that Jatropha curcas extract and vitamin E displayed similar effects on the animals.

\section{DISCUSSION}

Presence of secondary metabolites commonly referred to as phytochemicals have been shown to be responsible for various pharmacological properties of medicinal plants (Okajuku et al., 2006). Presence of steroid, terpenoid, tannin, flavonoid and saponin in the methanolic extract of the leaf of Jatropha curcas agreed with previous findings by Igbinosa, et al, 2009. Previous research work on different parts of Jatropha curcas has revealed the therapeutic potentials of the plants extracts as antimicro- 
Table 1. Summary of Phytochemical Constituents of Methanolic Leaf Extract of Jatropha curcas

\begin{tabular}{lc}
\hline Phytochemicals & Inference \\
\hline Flavonoids & + \\
Steroids & + \\
Terpenoids & + \\
Tannins & + \\
Phlobatannins & + \\
Cardiac glycosides & - \\
Saponins & + \\
\hline
\end{tabular}

+ Present, - Absent

Table 2. Effects of the extract of Jatropha curcas and Cadmium on concentration of Total protein, Albumin and Globulin in the Plasma of treated Animals

\begin{tabular}{lccc}
\hline Treatment group & Total protein $(\mathbf{m g} / \mathbf{d l})$ & Albumin $(\mathbf{m g} / \mathbf{d l})$ & Globulin $(\mathbf{m g} / \mathbf{d l})$ \\
\hline Control & $27.13 \pm 3.84$ & $5.18 \pm 2.34$ & $21.95 \pm 6.18$ \\
Cadmium & $10.35 \pm 2.42$ & $2.69 \pm 0.13$ & $7.66 \pm 2.55$ \\
J. curcas + cadmium & $19.14 \pm 1.90$ & $3.11 \pm 0.13$ & $16.03 \pm 2.03$ \\
Vit. E + cadmium & $17.76 \pm 1.90$ & $3.28 \pm 0.72$ & $14.48 \pm 1.18$ \\
\hline
\end{tabular}

The values are expressed as mean \pm SEM.

Table 3. Effects of Jatropha curcas extract and Cadmium on AST, ALT and GGT Activities in the Plasma

\begin{tabular}{lccc}
\hline Treatment group & AST (U/L) & ALT (U/L) & GGT (U/L) \\
\hline Control & $38.00 \pm 6.00$ & $16.40 \pm 4.91$ & $1.74 \pm 0.58$ \\
Cadmium & $92.00 \pm 8.00$ & $40.71 \pm 4.08$ & $31.27 \pm 1.16$ \\
J. curcas + cadmium & $41.00 \pm 1.00$ & $11.76 \pm 0.87$ & $1.80 \pm 0.55$ \\
Vit. E + cadmium & $43.00 \pm 7.00$ & $9.57 \pm 1.92$ & $1.74 \pm 0.58$ \\
\hline
\end{tabular}

The values are expressed as mean \pm SEM.

Table 4. Comparisons of the activities of Plasma AST, ALT, GGT, Total Protein, Uric Acid and Albumin between Jatropha curcas Extract and Vitamin E Pre-treated Groups

\begin{tabular}{lcccc}
\hline PARAMETERS & Control & J.curcas + Cd & Vitamin E + Cd & P<0.05) \\
\hline ALT & $16.40 \pm 4.91$ & $11.76 \pm 0.87$ & $9.57 \pm 1.92$ & NS \\
AST & $38.00 \pm 6.00$ & $41.00 \pm 1.00$ & $43.00 \pm 7.00$ & NS \\
GGT & $1.74 \pm 0.58$ & $1.80 \pm 0.55$ & $1.74 \pm 0.58$ & NS \\
TOTAL PROTEIN & $27.13 \pm 3.84$ & $19.14 \pm 1.90$ & $17.76 \pm 1.90$ & $\mathrm{~S}$ \\
URIC ACID & $0.21 \pm 0.16$ & $0.11 \pm 0.01$ & $0.18 \pm 0.07$ & $\mathrm{NS}$ \\
ALBUMIN & $5.18 \pm 2.34$ & $3.106 \pm 0.13$ & $3.28 \pm 0.72$ & $\mathrm{NS}$ \\
\hline
\end{tabular}

Values are expressed as Mean \pm SEM

bial (Ayelaagbe et al., 2000, Ayelaagbe, 2001 and Igbinosa et al., 2009) and antiparasitic (Fagbenro Beyioku, 1998). Phenolic compounds are known for their antioxidant properties, especially flavonoids. Presence of these antioxidant compounds in plants extracts is responsible for their protective effects against various degenerative diseases. They are able to protect the tissues and organs because of their ability to scavenge free radicals and prevent generation of other dangerous reactive oxygen species (Sachin et al., 2010).

Protein synthesis is one of the major functions of the liver. Thus total protein level in the plasma is often used as an indicator for health status. The results of plasma protein concentrations in different animal groups were 
presented in Table 2. Protein concentration reduced significantly from $27.13 \pm 3.84 \mathrm{~g} / \mathrm{dl}$ in control to $10.35 \pm$ $2.42 \mathrm{~g} / \mathrm{dl}$ in cadmium only group. This reduction can be attributed to destruction of hepatocytes by cadmium (Bondy et al., 2000). Total protein concentrations were higher in Jatropha curcas extract and vitamin E pretreated groups but lower in the cadmium only group. These protective effects of Jatropha curcas and vitamin $\mathrm{E}$ may be due to their antioxidant properties. The same trend was observed in the plasma albumin concentrations. Plasma albumin concentrations reduced from $15.18 \pm 2.34 \mathrm{~g} / \mathrm{dl}$ in control to $2.69 \pm 0.13 \mathrm{~g} / \mathrm{dl}$ in cadmium as shown in Table 2. The significant reduction observed in the plasma albumin concentration may be an indication of liver injury, but albumin synthesis is also sensitive to amino acid supply thus nutrition state plays important roles in albumin concentration (Harper, 1961).

High plasma activities of aspartate aminotransferase (AST) and alanine aminotransferase (ALT) are associated with inflammation or injury to liver cells, a condition known as hepatocellular liver injury. Damage to the liver typically results in a leak of these enzymes into the bloodstream (Mumoli, et al., 2006). Both AST and ALT are enzymes found in the hepatocytes, upon destruction of hepatocytes or due to an increase in the permeability of the hepatocyte membrane, these enzymes are released to the blood and the levels are consequently elevated (Blasco and Puppo, 1999). Cadmium is an established toxic metal; the toxic effects of cadmium manifest through the promotion of oxidative stress in the tissues and organs where it bioaccumulates. Activities of these hepatic marker enzymes were determined in the plasma of the experimental animals. The increase in activity of alanine aminotransferase in the plasma of animals in cadmium only treated group from $16.40 \pm 4.91 \mathrm{U} / \mathrm{L}$ in control to $40.71 \pm 4.08 \mathrm{U} / \mathrm{L}$ confirmed the finding of Bondy et al., (2000), that cadmium causes peroxidative effect on the plasma membrane of hepatocytes leading to enzyme leakage into the extracellular fluid. Significant reduction in the alanine aminotransferase activities were observed in the Jatropha curcas extract and vitamin E treated groups when compared with the control group. The activities reduced from $16.40 \pm 4.91 \mathrm{U} / \mathrm{L}$ to $11.76 \pm 0.87 \mathrm{U} / \mathrm{L}$ and $9.57 \pm 1.92 \mathrm{U} / \mathrm{L}$ in Jatropha curcas extract and vitamin $\mathrm{E}$ pre-treated groups respectively. Vitamin E and Jatropha curcas extract have antioxidant properties; they were expected to ameliorate the toxic effects of cadmium in the animals. The probable reason for this may be partial inhibition of the enzymes synthesis in the presence of cadmium.

Gamma glutamyltransferase (GGT) is another enzyme used in clinical diagnosis of liver disorders. GGT levels are elevated in disease of the bile ducts and in some liver diseases (Mumoli, et al., 2006). Elevation of the enzyme activities from $1.74 \pm 0.58 \mathrm{U} / \mathrm{L}$ in control group to $31.27 \pm$ $1.16 \mathrm{U} / \mathrm{L}$ in the cadmium only treated group also con- firmed liver damage. This result is consistent with the other results already discussed. Administration of Jatropha curcas extract significantly reduced the activity of the enzyme in the plasma significantly. Similar values were recorded for the control and vitamin $E$ group showing complete protection against cadmium toxicity.

In conclusion, the results of this investigation has further confirmed the inherent therapeutic properties of Jatropha curcas and also justified its uses in traditional medicine to cure various ailments in Asia, Africa and Latin America (Burkill, 1994). Methanolic extract of the leaf of Jatropha curcas can serve as a base for the discovery of cheap and effective hepatoprotective drug. Further research is required to investigate and isolate the phytochemical(s) responsible for this activity.

\section{ACKNOWLEDGEMENT}

We are grateful to the staff of Drug Research and Production Unit (DRPU), Faculty of Pharmacy, Obafemi Awolowo University lle-lfe, for the use of their Soxhlet apparatus and vacuum pump evaporator.

\section{REFERENCES}

Aiyelaagbe OO, Adesogan EK, Ekunday O, Adeniyi BA (2000). The antimicrobial activity of roots of Jateopha podagrica. Hook. Phytother. Res. 14: 60-62.

Aiyelaagbe OO (2001). Antibacterial activity of Jatropha multifida roots. Fitoterapia 72: 544- 546.

Babalola OO, Areola JO (2010). Interactive roles of terpenoid extract from the leaves of Azadirachta indica (A. Juss) on lead induced toxicity in pregnant rabbits. J. Med. Plant Res. Vol. 4 (12), pp11021107.

Burkill HM (1994). The useful plants of West Tropical Africa (Families EJ), Royal Botanical Gardens Kew, 90-94.

Blasco J, Puppo J (1999). Effect of heavy metals (Cu, Cd, and $\mathrm{Pb}$ ) on aspartate and alanine aminotransferase in Ruditapes philippinarum (Mollusca: Bivalvia). Comp Biochem Physiol Pharmacol Toxicol Endocrinol 122: 253-63.

Bondy GS Armstrong, CL Curran IA Baker MG Nnenta R (2000). Restrospective evaluation of serum ornithine carbamyl transferace activity as an index of hepatotoxicity in toxicology studies with rats. Toxicol Lett, 144 163-71.

Cannon DC, Olitzky I, Inkpen JA (1974). Determination of total protein in cerebrospinal fluid. Clinical Chemistry, Principle and Technique fluid. Clinical Chemistry, Principle and Tecnics $2^{\text {nd }}$ ed Henry, R.J., Cannon, D.C., Winkel-Man, J.W. Harper and Row, New York, 422

Edeoga HO, Okwu DE, Mbaebie BO (2005). Determination of Phytochemical constituents of Plants. Afr. J. Biotechnol., vol. 4 (7) 685-688.

Evans MD, Cooke MS (2004) Factors contributing to the outcome of oxidative damage to nucleic acids. Bioassays .26 (5):533-42.

Godt J, Scheidig F, Grosse-Siestrup C (2006). The toxicity of cadmium and resulting hazards for human health. J Occup Med Toxicol; 10 (1): 22-28.

Gupta MP, Monge D, Karikas GA, Cerain A, Solis PN, Leon E, Trujillo M, Suarez O, Wilson F, Montenegro G, Noriega Y, Santana Al, Correra M, Sandiez C (1996). screening of Panamanian medicinal plants for brine shrimp toxicity, crown gall tumor inhibition, cytoxicity and DNA interacalation, Int J. pharmacog. 34; 19-27.

Harper HA (1961). The functions and tests of the liver. Review of Physiological Chemistry. Lange Medical Publishers, Los Atlos, CA. 271-283. 
Hufford AE, Oguntimehin BO (1978). Non-polar constituents of Jatropha curcas. Loydia 41: 161-65.

Kambu K, Tona L, Kaba S, Cimanga K, Mukala N (1990). Antispamodic activity of Jathropha curcas extracts. Proceeding of Plant Antidiarrhea Traditional Preparations used in Kinshasa, Zaire. Ann Pharm Fr 48:200-08.

Mumoli N, Cei M, Cosimi A (2006). Drug-related hepatotoxicity. N. Engl. J. Med.

354 (20): 2191-3

Ogwuegbu MO, ljioma MA (2003). Effects of Certain Heavy Metals On The Population Due To Mineral Exploitation. In: International Conference on Scientific and Environmental Issues on The Population, Environment and Sustainable Development in Nigeria, University of Ado Ekiti, Ekiti State, Nigerian, 8-10.

Ogwuegbu M, Muhanga W (2005). Investigation of Lead Concentration in the Blood of People in the Copperbelt Province of Zambia, J. Environ. (1): $66-75$

Okajugu T, Etatuvie S, Eze I, Jimoh B, Nweke C, Mbagi C, (2006). Medicinal plants of Nigeria in collaboration with Lagos State Traditional Medicine Board and Botany Dept, University of Lagos $1^{\text {st }}$ Ed 2006 1;20.

Oteiza PI, Adonaylo VN, Keen CL (1999). Cadmium-induced testes oxidative damage in rats can be influenced by dietary zinc intake. Toxicol ; 137: 13-22.
Pinnel AE, Northman (1978). New automated dye-binding method for serum albumin determination with bromocresol purple. Clin. Chem.. 24 (1978), 80-86.

Reitman S, Frankel S (1957). Determination of Alanine aminotransferase activity. Amer. J. Clin. Path. 28: 56.

Rosaki SB (1975). Gammaglutamyl Transferase. Adv Clin Chem 17: $53-$ 107

Sachin SS, Archana RJ, Manoj NG (2010). Invitro antioxidant and antiinflammatory activities of methanol extract of Oxalis curniculata Linn. International J. Pharm. Pharmaceut. Sci. 2,(1): 146-155

Subramonium A, Pushpangadan P (1999). Development of phytomedicines for liver diseases. Indian J. Pharmacol. 31: 166-175.

Teitz NN (1957). Fundamentals of Clinical Chemistry $3^{\text {rd }}$ ed. Philadelphia, W B Saunders Co. 391.

Uche FI, Aprioku JS (2008). The Phytochemical Constituents, Analgesic and Anti- inflammatory effects of methanol extract of Jatropha curcas leaves in mice and Wister albino rats J. Appl. Sci. Emoron. Manage. 12(4) 99-102.

Ward FM, Daly MJ (1999). Hepatic Disease In: Clinical Pharmacy and Therapeutics (Walker R.and C.Edwards Eds.). Churchill Livingstone, New York, 195-212. 